\title{
Fraud and Governance: A Review June 2020
}

\section{Michel Sayumwe}

University of Quebec at Montreal, Canada

Email: sayumwe.michel@uqam.ca

Article History
Received: May 5, 2020
Revised: May 30, 2020
Accepted: June 8, 2020
Published: June 11, 2020
Copyright (C) 2020 ARPG
\& Author
This work is licensed
under the Creative
Commons Attribution
International
@) (4) CC
BY: Creative Commons
Attribution License 4.0

Abstract

This literature review is organized in five sections. Firstly, we begin with general ideas and continue with the origin of the fraudulent. Secondly, we discuss the struggle of the phenomena, insisting on the available mechanisms. Finally, we'll discuss the link between audit and fraud.

Keywords: Control; External audit; Fraud; Governance; Internal audit.

\section{Introduction}

In the following three subsections, we present general knowledge about the fraud phenomena. We'll analyze some definitions proposed by the literature, followed by the fraud cost and its roots.

\subsection{Definition of Fraud}

In the literature, many definitions have been proposed to the concept of fraud. For Wells (2007), fraud includes any crime that uses dishonesty as its operational mode. Taking into account the dishonesty, the robber uses its force as a mean to take money illegally. All the infractions that use stratagems are frauds. For Wells (2007), there is no fraud without stratagem. However, all the stratagems are not frauds. According common law, the presence of four elements is mandatory before concluding that there is fraud:

i) First, a material declaration

ii) Second, the declaration must be false at the moment that it is pronounced.

iii) Third, the victim must believe the false declaration

iv) Finally, in terms of consequences, fraud must cause damages. Fraud can destroy lives (Peltier-Rivest, 2010).

In business, accounting fraud or fraud to financial statements is well documented. It is defined as the use of accounting process and practices to mislead the users of financial statements (Hoi and Robin, 2010; Shapiro, 2011). This corresponds to the publications of false financial information (Zhou and Kapoor, 2011). With no consideration for their size, profitability or industry, all type of organizations are exposed to fraud (Mangala and Kumari, 2015). The fraud can take many forms: earnings increase, notional transactions, false declarations and assets thefts (Kambia-Kapardis, 2016). Corporate fraud is one of permanent threats with unexpected consequences (Zecri, 2008). On the other hand, Le Maux and Morin (2011) have adopted the definition of the Association of Certified Fraud Examiners $(A C F E)$ which categorize fraud in 3 types:

i. Embezzlement of assets

ii. corruption

iii. Accounting fraud

According to the ACFE, fraud is explained by psychological, social and economic factors. On the psychological level, we need to understand the reasons that encourage people to fraud. Le Maux and Morin (2011) suggest that the fraudster action is motivated by a malfunction in the individual development and his relationship with his environment.

Fraud is not only a corporate problem, even if it implies income loss for corporations. Fraud consequences are huge for governments and Society in general. No country is immune. Fraud has become a global problem and a prominent concern (Ali et al., 2013). Even on the family level, fraud exists. For example, for a few years, false marriages, false fatherhood and false tourists have been found (Spire, 2012).

It's important not to confuse error and fraud. Error is never made voluntary, because the person who made a mistake was not animated by a malevolent desire. In the case of a corporation, a wrong action of a manager doesn't have the aim to false financial data for a better organizational performance (Hass et al., 2016).

In the next subsection, we discuss the nature of the fraud costs. 


\subsection{The Fraud Costs}

Accounting literature has collected many statistics on the fraud costs and employees costs in businesses. The concept of fraud can undermine a company's reputation, without any chance to reverse the situation (Peltier-Rivest, 2010). Its consequences can be disastrous on society, very heavy financially, devastating for the trade and demotivating for the personnel (Zecri, 2008). No crime has more impact on the accounting profession than fraud (Free, 2015). Verschoor (2014), used the report of the ACFE to present cost elements related to fraud. He concluded that $5 \%$ of the total revenue of an organization is lost each year due to a corporate fraud. The situation has not improved when compared to previous years. In fact the 2012 annual report estimates a lost of 3.2 billions dollars when compared to the World GDP. In 2014, the median loss was \$ 145000 , more important of the 2012 median loss. According to the 2012 ACFE Annual Report, this meant a decrease of that kind of loss. In $20 \%$ of the cases, the loss was at list of 1 million dollars. In Canada, more than 34,5\% of fraudulent cases imply a loss of at least 500000 dollars for the victims while $25,6 \%$ of fraudulent cases imply a loss of at least 1 million dollars (Peltier-Rivest and Lanoue, 2015).

In scientific research, the fraud costs are huge for young scientists (Crocker, 2011). In the health sector, Pande and Maas (2013), based on FBI Reports, the average number of fraudulent doctors ordered to reimburse in the United States represents on average 185 times bank robberies in the country. Fraud in medical assistance cost between 60 and 250 billions dollars to taxpayers each year.

According to a study conducted in Turkey, Ilter (2014) concludes that banks and holdings controlled by nonreliable shareholders can push those organizations to divert public funds. These ill-intentioned shareholders are capable of illegally transferring very large sums from one group of companies to others without ever returning these amounts in the future. For the authors, those kinds of shareholders can use different fraudulent techniques in financial accounting to commit their package.

Shoplifting and distribution thefts cause unexplained costs of 5,3 billions of Euros in France, which represent $1,4 \%$ of revenue in that country (Perron and Djelassi, 2015)(. French managers prefer the deterrent approach to deal with the phenomenon. In 2011, french corporations have invested $0.32 \%$ of their revenue (1.369 billions euros) in security measures to fight deviant consumer behavior. However, their strategies did not prevent an amplification of the problem during the years 2012 to 2015. For Peters and Maniam (2016), the fraud impact is more important than financial consequences. In fact, the consequences of unethical acts not only affect the morale of the companies concerned but also affect that of the employees involved in their management. Fraudulent practices even push suppliers and other companies to doubt vital companies. They question the ethical behavior of the whole company. It takes time, consistent performance over a period of time, and good financial results for a business to rebuild its image when it has been tarnished by fraudulent activity.

Button et al. (2015), have identified a number of additional costs to take into account to the initial fraud value. We can cite the intangible costs, the costs of investigations, sickness of the employees, internal discipline, external sanctions, and those of permanent replacement of the personnel. Taking these costs into account resulted in a substantial increase in the initial loss. The study of Button et al. (2015) has been realized on 45 cases in England. The research found an increase of 265 per cent for fraud actions of less than $25000 \mathrm{GBP}, 117$ per cent for less than 100000 GDP, 45 per cent for the cases of less than one million British pounds. For other cases taken together, the losses increase for 14 per cent.

To promote good practices in accounting, auditing, risk management and the fraud examiner professions, it's important be more collaborative with universities. For this, Dorminey et al. (2012) encourage the integration of relevant concepts in academic programs and course contents. They offer what they call a meta-model that presents a framework for identifying potential areas for future fraud research, highlighting open questions regarding the characteristics of fraudsters, understanding combinations of characteristics as background fraud and recognize the effects of these characteristics on the probability of fraud. Using this framework as a foundation would allow future research to delve into unexplored areas, such as interactions between constructs, mediation and the moderation effects of controls, and better tools or approaches to improve detection procedures. The use of legislation with laws such as that of the Sarbanes-Oxley Act of 2002 makes it possible to reform corporate governance by limiting the opportunities for fraud. But, this formula is not applicable to elements on which one cannot legislate. This is the case for the ethics and integrity of individuals.

Therefore, in deterrence and fraud detection strategies, the focus should be on interpersonal and behavioral factors: the psychology of the fraudster as well as that of those charged with governance, including auditors and their interactions. The fraud triangle, which consists in opportunity, pressure, and rationalization, is an excellent framework tool to understand causal roots of fraud and the foundation of consequent behavior. We also have to consider another fraud triangle, which put an accent on the act, its dissimulation and conversion. If most of the time, those who commit the crime do it on behalf of their organizations, it is legitimate to seek to understand their motivations and to determine both why and how the crimes of money laundering are perpetrated. The study showed that the factors influencing the behavior of the fraudster are the key elements to consider in providing a deterrent, detective and preventive response to acts of fraud in the financial statements. We will see that when we move into the field of fraud and remediation investigation, the use of behavioral science becomes even more interesting (Ramamoorti, 2008). To reduce fraud in financial statements, which include detection and prevention, Gupta and Gill (2012) propose the use of predictive and exploration techniques of data used in the literature. Jacquinot et al. (2011) believe that in a business, the top leaders must be role models. If they have deviant behavior, there is a high probability that the phenomenon will spread to several levels of the organization. This is what has happened in a 
French mixed economy society where the president has embarked on fraudulent activities. Starting from this, fraud gained momentum when it gradually spread throughout the company. Without being invited or incited by managers, employees have embarked on illicit activities. Employees at all levels have strengthened themselves in what the authors call addiction. They explain it as a climate that can lead both leaders and subordinates to become involved in fraudulent activities due to tacit collusion between actors. Still according to Jacquinot et al. (2011), in addition to addiction, imitation is another factor used by the authors to explain this case of generalized fraud. Indeed, the subordinates imitated their leaders who defrauded to do so in their turn. The latter could not even sanction the employees because of the fact that they were themselves involved. Any attempt to arrest an employee would expose the manager to be also denounced by the employee in question or other members of the organization. Corruption is a form of fraud. Its impact on countries is not presented in the same way. In other words, depending on the political environment, the consequences may vary. In cases where the indicators of corruption are very high, Rehman and Perry (2014) find in research that economic performance is good. They cited the cases of Qatar, Kuwait and the United Arab Emirates, for example. The user of the World Bank's governance indicators indicates that they are less corrupt in several aspects, except the rule of law, corruption control and political stability. The Consequences of fraud brings society to better understand the reasons why we are interested in ethics and morality and the resulting use of moral and conduct values in creating ethical climates in organizations (De Cremer and Wim, 2017).

\subsection{The Causes of the Fraud}

In our era, capital markets are characterized by intense competition. To place themselves in better positions, companies often use fraud and manipulation (Yucel, 2013). The discretionary power of the personnel responsible for management in the organization gives them the opportunity to manipulate the financial reports of companies in order to achieve the desired objectives (Hasan et al., 2016). For these authors, certain factors such as the inefficiency of the capital markets, poor corporate governance, institutional weakness, the insufficiency of competent independent directors, the absence of audit, the duality of CEOs, of investors institutional property limited, majority family ownership, political ties, lack of qualified accountant, etc. create opportunities for falsifying corporate financial reports.

Sometimes companies present themselves as if they are performing well during a given period, when their real financial situations are catastrophic. Some business leaders cheat to hide the reality. They engage in bad behavior in an attempt to give the impression that the moments are still good (Finnerty et al., 2016). A study carried out in France by Djama (2013) showed that the publication of financial reports would have had a positive impact on the financial market, while the initiation of an investigation by the authority of the financial markets would reduce the price of financial assets, whereas the announcement of sanctions would have no significant effect. In his study carried out in 2014 as part of the Bangladeshi economy, Hasan et al. indicated that management was the only place for preparing fraudulent financial statements and the incidence of management expediency in fraudulent financial reports and the incidence of management expediency in corporate financial reporting is very high.

Many studies have found a link between the manager's compensation and corporate fraud. Chief executive officers (CEO) are paid 7,6\% less than less than those who do not defraud. For managers who are implied in severe fraud acts, this percentage decreases to $5 \%$ (Conyon and Lerong, 2016).

The compensation schemes of business leaders lead some of them to defraud. Indeed, in the quest for better performance on the part of managers, they are offered compensation schemes, such as stock options, which depend on the value of the firm. This strategy allows them to assume a certain risk which is based on their performance. This risk encourages managers to defraud (Robinson and Santore, 2011). Options have a more powerful impact on the manipulation of financial data than on the real value of the company's action (Peng and Roell, 2008). The incentives envisaged for business leaders increase their propensity to commit acts of fraud.

According to Alam and Petruska (2012), there is a link between accounting conservatism and fraud. In a study of accounting conservatism, the SEC investigation into fraud concluded that the accounting of fraudulent companies is very conservative. Accounting conservatism decreases in these companies with the detection of fraud.

Reliable internal control can be a source of tax fraud. According to Azrina et al. (2014), faced with weak or nonexistent internal control, senior executives in companies have a great opportunity to defraud to the detriment of the taxman. There are a lot of opportunities to leverage investments that meet standards. Those who benefit from the system work in setting up a structure to control. On the other hand, still according to Chen and Galbraith (2012), when an economy is characterized by scarcity and austerity, there are few possibilities of big profits for honest companies. However, due to the pressure from the financial markets, profits must remain high. However, to maintain such a level of profitability, the main players commonly resort to fraud. The following section explains the origins of the fraudsters.

\section{The Origin of Fraudster}

We are going to discuss the difference between fraudsters from outside and those from inside (employees, managers) who are involved in acts of fraud.

Organizations are susceptible to fraud by internal people (Johansson and Carey, 2016). Employee fraud can be classified into three categories: embezzlement (an employee steals or abuses the resources of an organization), corruption (an employee violates his duty to the employer in order to obtain an advantage direct or indirect) and financial statement fraud with the intent to deceive, an employee misallocates or omits important information in the organization's financial reports (ACFE, 2014; Shanikat et al., 2014). 
In a model presented by Davis and Pesch (2013), two categories of fraud organization are to be considered. In an organization, heterogeneous individual agents who each have the motive and the possibility of committing fraud and a pro-fraud attitude interact with each other. From this interaction is born a cultural transmission mechanism through which attitudes about fraud can spread. In the first category, fraud tends towards a stable level. In the second, it manifests itself through extreme behaviors. Generally honest organizations can, at random over time, start to defraud. The reverse is just as possible.

Lisic et al. (2015), analyzed the relationship between accounting fraud and audit. Their review focused on the impact that the size of the audit firm could have on accounting fraud in a growing economy like China's. Chinese companies operate in a very specific environment. According to the authors, the Chinese government is directly involved in detecting accounting fraud in businesses. According to Shanikat et al. (2014), in accounting operations, fraud involves intentional actions carried out by illegally using a station and by diverting resources from an organization. In these financial documents, fraud is costly for investors and can damage the credibility of the audit profession (Wuerges and Borba, 2014). It is not just employees who can defraud their employers. It often happens to meet cases where the client wants to own property without going through the normal route. In a study carried out in January 2015, researchers Frédérique Perron and Souad Djelassi were interested in studying how the deviant behaviors of consumers who display these behaviors opposed to standards cause harm to many stakeholders in the trade of detail. To prevent these acts of deviance, detect them and dissuade the perpetrators, resources are used. Both the phenomenon and the means put in place to counter it have impacts on distributors, the employees concerned and consumers.

The study by Perron and Djelassi (2015) revealed that consumer perception is mixed on the question. This research allowed consumers to be classified into three categories. The first group is made up of those who are partially tolerant of fraudsters. They do not encourage their actions contrary to standards. However, they do not systematically and unreservedly condemn their bad behavior.

The second group is made up of those who display what the authors call a permissive attitude. For these consumers, if their peers do not meet the standards, there are extenuating circumstances to consider. So Therefore, they don't condemn them. The tolerance level for this group is total.

As for the third group, with firmness and rigor, it believes that acts outside the norm must be repressed. Consumers belonging to this group accept that certain deviances are understandable; they deplore them but no question of apologizing. The tolerance level for this group is total. Whether the fraud comes from inside or outside, it causes harm. It must be fought. In the next section we tackle the literature on the fight against fraud.

\section{Fight Against Fraud}

Fighting against fraud is a big challenge. For this, many stakeholders have to cooperate. In fact, it is necessary for the public and private sectors to be involved in fighting against accounting fraud (Beneish et al., 2013). To play its part in the battle, the first can use the regulators of the financial market and security. Through legislation and law enforcement, it can reduce fraud. As for the private sector, it can manifest itself by helping to identify companies likely to have manipulated financial data and to use market-based disciplinary mechanisms to make them accountable.

\subsection{The Social Necessity of Fighting Against Fraud}

For Boyer (2007), crime, crime prevention, and law enforcement are still major issues for society. Fraud is one of the elements targeted in this battle. The fight against fraud is not easy to win. The economy is dominated by two types of agents. On the one hand are those who report the facts of the world as they happened. The author designates them the concept of truth. On the other side are the dares: These are the people who swear to change the versions of facts to present them in the way that suits them. There is no way to separate them very clearly. We cannot rely on the amount of fraud to determine the exact proportion of dares in the economy. If the proportion of dares is very high, the author believes that investing in fraud prevention can be a waste of resources, since such an investment will not prevent deviant behavior.

When their proportion is low, investing in prevention reduces fraud. Corporate financial fraud affects the financial market in general (Throckmorton et al., 2015). To address the problem of fraud in the financial statements, it is necessary to put in place strong internal control systems, and to clearly define the roles and responsibilities of all the responsibilities of all parties with regard to records in the financial statements to prevent and detect fraud. However, all stakeholders have a role to play in ensuring the reliability of financial statements (Zager et al., 2016). To better understand the role of managers in corporate fraud, Cohen et al. (2010) combined the fraud triangle with the theory of planned behavior (Theory of planned behavior). Depending on their outcome, fraudulent behavior can be explained by several elements related to the way fraud is perceived by the fraudster. Three of these are components of the theory of planned behavior. However, they are not included in the auditing standards in place to combat fraud. These are attitude assessment, subjective norms and perceived behavioral control. Auditors should consider them in the management ethics review. In the fight against fraud, through professional standards, we must reinforce the emphasis placed on the behavior of managers who may be associated with unethical behavior.

According to Mangala and Kumari (2015), in the fight against fraud, measures must be considered both to prevent it and also to detect it. Prevention is about trying to prevent fraudulent acts from being committed. The authors analyze first the nature of the fraud, the consequences, the scheme of the act and the means of prevention. Once this information is obtained, it must be integrated into the control system and appropriate follow-up must be done to avoid its reproduction. Thus, there would be a link between prevention and detection. Detection methods 
make it possible to discover acts of fraud and to report them to the competent authorities. One of the key factors in ensuring good quality financial statements is fraud prevention.

Generally, two conditions are necessary so that the use of stock options is not problematic: first, suspensive clauses are essential to guarantee the efficiency of the contractual relationship; second, public policy must integrate the complex effects that we have highlighted in the dual agency relationship (Fleckinger et al., 2013). The financial crisis from 2007 to 2009 was caused by widespread fraud in the mortgage securitization industry (Fligstein and Rochrkasse, 2016).

The fight against fraud at national level requires significant resources. In a country where the government is starting to apply austerity measures, the impact can be reflected in the performance of the battle against fraud. Public sector fraud and financial crime is a major challenge in England, to the point that the country is taking a zero tolerance approach to tackling it Frimpong (2015). However, the conclusion of Frimpong's research is austerity measures adopted by the government, which imply a reduction in the resources allocated to the battle against fraud. This policy leads to a regression in the country's capacity to combat the scourge.

In France, it is reported that the annual losses of the State due to tax evasion (tax evasion and tax avoidance) are estimated between 42 and 51 billion euros (Compin, 2015). The country considers this category of fraud to be a serious problem. He decides to lead a fight on three levels to fight it (Oriane and Lafuente, 2014). First, at the administrative level, the State broadens the powers of the tax administration by enabling it to be better able to seek out and punish offenders.

Secondly, on the international level, France is banking on the enlargement of its network of countries with which it can have tax data exchange agreements to fight against evasion. In order to persuade potential fraudsters, this European State is counting on the strengthening of sanctions. At the same time, there is provision in tax laws to reduce the penalties for repentant fraudsters.

In Belgium, tax fraud and other underground activities pose many problems for the economy (Oriane and Lafuente, 2014). While the country is in debt and heavily taxed and taxed, it cannot collect everything it should from a tax perspective. In their study, these authors were interested in the possibility of assessing the importance of tax fraud and explaining the behavior of taxpayers who engage in it. They concluded their work by specifying that in the literature, taken in isolation, several studies offer information on tax fraud, but they do not have a reliable assessment of the phenomenon. However, for Spire and Weidenfeld (2016), tax fraud is unconsciously tolerated by French judges. Indeed, for tax fraud greater than 153 euros, the offender should be subject to criminal prosecution. This severity is not translated into the facts. In fact, out of the 16,000 files indexed due to tax defaults, the tax administration only examines a thousand cases. Revenue losses linked to social and tax fraud amounted to 20.4 billion euros in 2009 in Belgium. From 2009 to 2015, the deficit to be mopped up should increase to 25 billion euros. The Belgian underground economy was worth between 4 and 18\% of this country's GDP (Pacolet and Stren, 2011). Ali et al. (2013), present PRIDIT-FRE, a method for estimating the rate of fraud in a set of claim files received by an insurance company. To apply PRIDITE-FRE, we need a small verified sample and easily obtained fraud predictors. In business practices specializing in fraud management, the estimate of the fraud rate obtained using this method can be integrated and will generate significant cost savings. It is difficult to speak of fraud without mentioning money laundering silver. The new forms of payment of the era we are living in facilitate the activities of money laundering criminals. On the other hand, it offers countless benefits to society. It even allows the verification of the identity of fraudsters who practice money laundering and other surveillance activities to prevent this type of fraudulent acts. Besides the economy, fraud strikes other sectors of society. In the politics of certain countries, it is also in full swing. In democratic societies, the renewal of political staff is done through elections. It turns out that fraud is part of electoral processes. The integrity of the latter is based on fair procedures. However, this equity is the subject of major threats because of fraud, which can affect it in many cases and in different forms (Leemann and Bochsler, 2014). Electoral fraud is linked to the level of the State concerned. In countries where state infrastructure is weak, the probability of having fraudulent elections is higher. Intimidation of voters and candidates, fraudulent tabulation of votes, unfair media coverage of campaigns, and vote buying are among the methods used by fraudsters to defraud elections (Fortin-Rittberger, 2014). The consequences of fraud on society are extremely serious. Voices are even rising to say that the death penalty could be a deterrent to white-collar criminals aspiring to commit mass crimes such as financial fraud (Hossain et al., 2017). In our view, this solution is extreme and would not necessarily solve the problem of fraud. One cannot fight against fraud without detecting it (when the crime is already committed) and preventing it (by acting upstream to prevent it from happening). Components will be reviewed in the next two subsections.

\subsection{Detection}

In a research by Albrecht et al. (2015), it has been revealed that educating employees and other citizens about the consequences of fraud helps to detect it early enough to reduce their negative impact on the working environment. In the case studied by Albrecht et al. (2015), it has been shown that fraudsters often use their powers to recruit people to participate in their acts. Recruitment is based on several factors. They cite for example the desire of a subordinate in order to receive rewards and advantages, his fear of punishment, his perception of his personal knowledge, and his needs for personal relationship. Once recruited to participate in acts of fraud, this employee himself became a recruiter of other individuals who work under his authority. The latter will in turn involve their subordinates. This will continue until an individual decides to sound the alarm or until the dishonest acts become so large and egregious that they are discovered. From an economic and social point of view, corporate fraud is a major problem. Whistleblowing is the best way to combat it Rossana et al. (2013). No matter when fraud is discovered, 
there will be no impact on intentions to report. However, intentions to report fraud can be reduced when employees perceive the management's lack of responsiveness to launch an investigation (Lowe et al., 2015). For Kaplan et al. (2011), the intention to report does not depend on the gender of the employees. However, the authors show that women are more likely than men to report fraudulent financial reports on the condition of anonymity. Whistleblowing sometimes involves difficulties for the whistleblower. The denunciation leads the actor to a professional blockage or encouragement. The interaction between the individual and the social system contributes to the professional resilience of the whistleblower. For Petit and Cusin (2013), resilience "must be seen as the process which combines, over time, the interactions between an individual and the social system in which he evolves. Resilience is therefore not only psychological. It is more fully understood by the system of interactions with the environment and follows three key moments: stigmatization, rehabilitation and reintegration. This new way of looking at an individual's resilience, the role of resilience tutors present in the social environment is central. Auditing can play an important role in exposing fraud. In this sense, Kaplan et al. (2011) have shown that an auditor who questions is more likely to obtain a statement about unrequested fraud. Employees therefore feel more comfortable reporting a colleague to an internal auditor than to the external auditor. Kummer et al. (2015), looked at the effectiveness of fraud detection instruments in non-profit organizations (NPO). Generally small, these organizations do not always have the resources to set up systems capable of protecting them against fraud. The characteristics of those who defraud in these organizations bring them very close to the fraudsters identified in other contexts. The real difference becomes clearer at the level of the victims (Holtfreter, 2008). The study of this author revealed that, in terms of education, fraudsters in this type of organization and those in other sectors are similar. However, the fraud detected in non-profit organizations (NPOs) was more often perpetrated by women and self-employed workers, that is to say volunteers. The scale of fraud cases decreases with the size of the NPO. Indeed, the larger the organization, the more it is able to provide the means of protection against fraud (Holtfreter, 2008). According to Kummer et al. (2015), it has been suggested in the literature that NPOs are more vulnerable to fraud. Their dependence on trust, the weakness of their internal controls and their lack of commercial and financial expertise are some of the elements that can explain this vulnerability. Research by these authors is similar in conclusion, concluding that the risk of fraud in this sector is significantly higher than what the cases of fraud discovered indicate. If in some cases, the detection rate is low, the authors believe that this could be explained by the lack of appropriate fraud detection and prevention measures. He suggests that measures be taken upstream to preserve the reputation of NPOs. Thus, it is necessary to rely on the effective and early detection of fraud. By taking corrective measures such as adjusting internal controls and prosecuting fraudsters, as time goes by, organizations will be able to reduce other fraudulent behavior. In a recent study, Johansson and Carey (2016) focused on examining the effectiveness of anonymous tip lines in detecting fraud against businesses. They analyzed data from 231 Australian public companies that responded to KPMG's bi-annual fraud investigations. The results showed that there was a positive relationship between the anonymous whistleblowing strategy and fraud reported only in small businesses, not large ones. Their research also showed that having an independent board of directors does not directly influence the detection of fraud. However, the presence of independent counsel in an organization implies the establishment of anonymous reporting lines, which will help detect more fraud. Then, it is legitimate to deduce that the authors find that the independent boards of directors contribute, by transitivity, to the detection of the fraud. Forensic accountants have higher levels of knowledge and skills in assessing the risk of fraud than auditors. They are therefore more effective in prevention, detection and offer responses to fraud cases (Popoola et al., 2016). Certain skills are necessary for a forensic accountant to succeed in his profession. These skills include detail orientation, persistence, ambition and high organizational skills. The forensic accountant often has to explain complex financial concepts to an audience that barely knows basic accounting concepts. So, it must be creative (Mukoro et al., 2013). The requirements for detecting, defining and reporting fraud have become more stringent than they have been before. To achieve the detection of fraud, the exclusive use of financial statement information is not enough. It is also necessary to make use of data mining techniques for the detection of fraud. Financial fraud is detectable based on the outlook of the organization. The better these are, the more they can be used for detection (Tarjo and Herawati, 2015). Accounting indications of increased revenues and profits cannot be used to detect financial fraud. However, depreciation, selling costs and other items can be used to detect fraud. The author proposes the Beneish M-Score model to detect financial fraud. The ratios "current assets / total assets", "average stock / total assets" and "total income / total assets" can be used to detect financial statement fraud (Nia, 2015). Other ratios also make it possible to distinguish fraudulent companies from those which do not fraud: "total debt / total assets". In short, leverage, capital turnover and the overall financial situation greatly help in the detection of fraud (Dalnial et al., 2014). Yu and Yu (2011), found that fraudulent companies invest $77 \%$ more money in lobbying than moral businesses. In the middle of a fraud, their investments to lobby further increase by $29 \%$. Thanks to lobbyism, these companies are increasing the time it takes to detect fraud. It also allows managers to have enough time to dispose of the shares they hold in such companies. No system has the means to detect fraud automatically. Detection is rather a manual activity based on the acquisition of knowledge in fraud strategy, concealment models (Shapiro, 2011). In the banking system, there is no guarantee that fraud can be eradicated even with the most advanced information technology applications (Sanusi et al., 2015). This is not unanimous in research. In an environment where financial fraud is evolving, computers equipped with detection tools with specific knowledge in the field (Zhou and Kapoor, 2011). Computer techniques and data mining software can be used as a mechanism to prevent and detect fraudulent transactions and accounting fraud (Segal, 2016). 


\subsection{Fraud Prevention}

Prevention is better than detection. It avoids the diversion of huge amounts of money (Ravisankar et al., 2011). In the case of an inadequate internal control system, weaknesses can be compensated for by informal mechanisms (Zawadzki, 2013). According to the author, the managers of family-run small and medium-sized enterprises (SMEs) manage to control the risks of fraud without going through internal control and management procedures. To do this, they use informal and individual factors. Zawadzki (2013), is not alone in proposing to include the use of informal mechanisms in the fight against fraud. According to Le Maux et al. (2013), governance mechanisms such as the board of directors, the audit committee, the external auditor, shareholder activism and internal control play a key role in the fight against fraud. Internal control can be a great opportunity for fraud, because its existence creates a feeling of trust. If not enforced, fraudsters can take advantage of the protective impression that comes from monitoring to allow their dishonest acts (Bierstaker et al., 2010). In a study carried out on fraud in Indonesian universities, Zamzami et al. (2016) conclude that operational audits, the review and improvement of internal control, the examination of monetary assets and the code of sanctions against suppliers / contractors and ethics officers are the five most effective procedures for detecting and preventing fraud. In the presence of high risks of fraud, auditors have an interest in using brainstorming and strategic reasoning to modify the nature of their audit plans in order to make them more effective or adapt them (Hoffman and Zimbelman, 2009). A study by Hogan et al. (2008) has shown that auditors do not change their audit plans when they see a serious risk of fraud.

In the banking sector, administrative and technical controls can be used to prevent fraud (Rayaan et al., 2016). Two prevention methods allow a $10 \%$ improvement in the performance of fraud forecasting compared to the best current techniques (Perols et al., 2017). On the one hand, the problem of data scarcity in terms of fraud detection must be addressed. On the other hand, fraudulent financial statements should be subdivided into several categories. The results obtained with these two methods will also improve the performance of the Securities and Exchange Commission (SEC) and audit firms in detecting fraud.

Finnerty et al. (2016), considered that finding a surprisingly good stock price performance for a listed company is a harbinger that regulators and investors must take seriously. In fact, their research has shown that fraudulent companies maintain abnormal and abundant performance for the five years preceding the discovery of their nonstandard activities.

In organizations, it would be better for owners to place more emphasis on the fraud triangle for theft and loss prevention rather than blindly investing in the trust of their employees (Kramer, 2015). Thus, they could decrease the opportunities by creating the perception of detection of any infraction. With prevention, small business owners and managers will reduce the risk of fraud. For the author, it is necessary that the owners take certain measures such as the direct collection of bank statements and random reconciliations several times a year. In addition, access to bank accounts and company inventory should be restricted. Owners can set up a system allowing employees to report suspected fraud without fear of reprisal.

For Reinstein and Taylor (2017), rationalization is the key factor in fraud. Yet the accounting profession seems to focus on pressure and opportunity while ignoring rationalization. This factor allows accountants to minimize their personal responsibilities when they become involved in fraudulent acts. The authors believe that preventing accountant fraud involves ethical development. The values underlying ethics provide protection to help prevent accounting professionals from finding themselves in positions where they may feel rushed to commit fraud. Detecting and reporting fraud, especially when it is serious has a negative impact on the market price of the victim organization (Aggarwal et al., 2015).

Still with regard to rationalization, the results of research by Harvey et al. (2017) suggest that one should start by finding a better explanation of how people justify deviant behavior by examining attributive and emotional processes. Secondly, we should try to circumscribe the conditions under which individuals may find accomplices so that they are tempted to justify themselves by engaging in fraudulent behavior.

The prevention of fraud risks cannot be of a one-off nature. It must be a continuous process driven by management control and internal control (Zecri, 2008). In the insurance industry, giving the impression of uncertainty about fraud detection can be an effective strategy to deter agents who make fraudulent claims (Lang and Wambach, 2013). In addition, the authors believe that it is not always optimal to invest in an audit strategy. Indeed, if the audit costs are heterogeneous among insurance companies, the ambiguity that characterizes the audit strategy to detect fraud will be eliminated. In other words, the authors recommend safeguarding the uncertainty linked to the detection of fraudulent claims. Cordery and Baskerville (2011), discuss fraud related to charities. The fact that the latter do not make its main partners responsible for fraudulent acts, says the authors, a kind of encouragement for the prosecution of fraud. Their report recommends stakeholders by administrators of charitable organizations. This understanding will manifest itself through the importance accorded to their moral rights by taking measures aimed at reducing cases of fraud within these organizations. In the public sector, the authors (Panagiotidou and Intzesiliglou, 2016) have highlighted the existence of fraud in the purchasing sector. The choice of suppliers should be the result of a competition to choose the best offer in favor of the State. Unfortunately, this is not always the case insofar as the rules are still not respected, since those responsible for purchases or supplies can enter into schemes with any supplier to award him the contract for a return advantage. To prevent such fraud, the authors recommend that people working in the public sectors be given appropriate training to limit the choice of diversion in these organizations. Specifically, the authors recommend the use of education and management of social structures as key factors to reduce unfair maneuvers in public acquisitions.

We have just reviewed the literature on the fight against fraud, including detection and prevention. Let us now review the mechanisms used to lead this fight. 


\section{Mechanisms to Combat Fraud}

Within organizations, structures are put in place to fight against fraud. In the following sections, respectively, we will look at governance, internal control and external audit as the means used to deal with fraud.

\subsection{Fraud and Governance}

In the fight against fraud, governance has a fundamental role. Hatice et al. (2004) analyzed the impact that certain characteristics of the board of directors could have on the emergence of fraud in the company. In their analysis, they considered elements such as the composition of the board of directors on the emergence of fraud in the company. In their analysis, they considered elements such as the composition of the board of directors and its control committees: audit, compensation and appointment. The results of the study revealed that the composition of the board of directors and the control committees are significantly linked to acts of fraud in companies. In a company, the fact that the members of a board of directors are part of the board can be favorable to the emergence of fraud. This emergence is significantly linked to the independence of the control committees (audit, compensation). On the other hand, the presence of independent members of the board of directors who are not part of the board of directors would help to curb fraud, since the risk of conflict of interest is lower. Cumming et al. (2015), for their part, suggest that gender diversity on the board of directors would moderate the frequency of fraud. Risk analysis and management is both a mechanism in an organizational system and a tool in its own right for the prevention of unfortunate events. However, it must be recognized that the importance attached to it varies from one organization to another depending on the size, activities and general profile (Power, 2013). Zager et al. (2016), were interested in studying the roles and responsibilities of boards of directors, management, audit committees, internal and external auditors in the prevention and detection of fraud in the financial statements. These stakeholders play a fundamental role in the reliability of the financial statements. Research has revealed that abnormal techniques of overestimating assets and underestimating liabilities are the primary means used to falsify financial statements. Non-recording of expenses, unrecoverable assets and provisions for risks and losses are some of the main ways to underestimate expenses. To produce the opposite effect, that is to say overestimate them, costs are generally recognized at inappropriate times. On the other hand, for the overestimation of the financial results at the end of the financial year, companies register products in advance, fictitious products or enter them in duplicate. The findings of the study suggest that inventory thefts are more common, but fraudulent financial statements involve the largest losses. In an organization where the CEO develops relationships with the leaders best placed on the bottom line of business decisions, the probability of fraud increases (Khanna et al., 2015). The same applies to the connections established in the executive suites and the meeting rooms between these senior officials. In the latter case, according to the authors, we must add the reduction in the probability of detecting fraud. It should also be noted that the authors did not find any significant impacts between the probability of fraud in a business and the links woven through various other organizations (past employment, school or university) and these important leaders.

\subsection{Internal Control and Fraud}

The purpose of internal control, as a process, is to provide assurance regarding the effectiveness and efficiency of business operations, the reliability of financial reports and compliance with applicable rules and laws. A good internal control system, correctly applied, could add value to the company (Aris et al., 2015). In the literature, the fraud triangle presented by Cressy et al. (2012) is often cited as a tool to consider in detecting fraud.

This triangle represents three categories of indicators that encourage a person to commit fraud, namely pressure, rationalization and opportunity (Mangala and Kumari, 2015). For some authors, pressure refers to a situation or event that increases stress and raises the need to commit fraud. Rationalization develops the mindset to justify fraud in the current circumstances. Opportunity is the "ideal" situation for the appearance of fraud. The other two factors, rationalization and pressure, depend on the psychological condition of the fraudster and are not observable (Dorminey et al., 2012).

Peltier-Rivest and Lanoue (2012), found a positive relationship between the position of fraudsters and collusion among the explanatory factors for fraud. Indeed, these two elements create the favorable opportunity for dishonest employees to circumvent internal control, in order to commit acts of fraud. However, they encourage organizations to set up internal control systems that are best suited to their activities in order to reduce risks and losses to their simplest form. These systems must obviously be designed to reduce the risk of collusion. They admit, however, that more modest controls, such as segregation of duties and anonymous whistleblowing lines, can also be very effective in preventing and detecting major frauds before they cause irreversible financial damage to the organization. Fraud indicators detected by auditors are not always considered. For amounts deemed too low, they prefer to ignore them so as not to affect the performance of the company (Omar and Din, 2010).

Internal control is defined as a process, which is an integral part of the actions and activities carried out on an ongoing basis by Management and all employees with the aim of providing reasonable assurance that the objectives of the organization will be achieved through effective and efficient management, the reliability of financial statements, the safeguarding of state assets and compliance with laws and regulations (Puspasari and Suwardi, 2016).

Internal control is thus an important means available to the company to both prevent and detect cases of fraud (Jessup and Noblet, 2012). The more ineffective the internal control, the more likely the company is to be the victim of serious cases of fraud (Moyes et al., 2006). In the literature, we have not found research showing that there is a way to assess the level of moral principles of employees in an organization. In the absence of internal control, people 
with high moral standards will not commit accounting fraud. On the other hand, for those with a low level of ethical principle, the absence of internal control then leaves the field open to fraud by creating opportunity, which is one of the three elements of the Cressey fraud triangle. In Malaysia, for example, the universe of fraud in banking institutions is very sensitive and expansive. Internal control has a key role to play in dealing with this situation. Full compliance with standards and best practices in risk management and internal control will considerably reduce the extent of the phenomenon (Sanusi et al., 2015).

\subsection{Fraud Internal Audit and External Audit}

Although more than half of the external auditors have information on the red flags, only $20 \%$ of them use these indicators to detect in the financial statements (Yucel, 2013). Knowing the causes of fraud is useful in preventing and detecting it Wuerges and Borba (2014). Failure to do so can harm their client as much as they harm themselves. But, on the other hand, an increased likelihood of fraud can also benefit both. When there is a high probability of fraud, the auditor is encouraged to provide the audit resources that best meet the client's needs, which results in higher costs for the client. However, this is not a loss for the latter. In the form of higher audit fees, it recovers these additional costs incurred. Recovery can also come as a fraction of the added value it delivers to the customer. So the two are winners (Lin et al., 2015). To differentiate a high risk of fraud from a low one, (Fortvingler and Szivos, 2016) recommend breaking down the methods for assessing fraud risks. According to the results of their study, the higher the risk of fraud, the more auditors will feel the need to consult forensic accounting experts.

For Hammesley et al. (2011), fraud detection can be improved if experienced senior auditors who plan, conduct and supervise a large part of audit missions can identify specific risk factors and use this knowledge to specify effective and efficient tests. Such knowledge would allow them to improve their ability to identify new problems and respond to changes in risk factors during the audit.

Markelevich and Rosner (2013), have shown that the companies most likely to be penalized by the Securities and Exchange Commission (S.E.C.) for fraudulent acts are the ones with the highest audit ratings. Audit fees and other consultancy services, for example, have some connection to corporate fraud. On the one hand, Khanna et al. (2015) noted the weakness that the relationship between CEOs, senior managers and directors could cause in detecting and reducing fraud. The CEO in his relations with senior executives and directors could help fraudsters by providing them with the support necessary to execute their plan. After the internal mechanisms, let us now see the external audit which plays an important role in the faithful image of the financial information conveyed by the company.

In perception, internal audit is often used to detect fraud. But in reality, it is less effective than one might think. According to ACFE (2014), in 2010, 2012, and 2014, only 4.6\%, 3.3\% and 3.0\% of fraud cases respectively were detected by the external audit. With $40.2 \%, 43.3 \%$ and $42.2 \%$, councils rank first among the most effective means of detection. However, internal and external auditors do not see the important risk factors for fraud in the same way. Internal auditors pay more attention to competition, which is an important risk factor for fraud (Moyes et al., 2013). It is important to emphasize that external auditors are not required to detect fraud. The public is waiting for them to carry out fraud risk assessments. In order for them to meet this expectation, appropriate training should be provided (Hassink et al., 2010).

According to the results of a study by Lisic et al. (2015), companies audited by large firms have fewer fraudulent financial statements. The authors pointed out the effect of the State's involvement in the detection of accounting fraud and the sanctions imposed on auditors who have failed in their obligation to provide quality work. These results agree with those of Norazida and Handley-Schachelor (2014) who revealed that the integrity of managers and the establishment of a good control system could help prevent the preparation of fraudulent financial statements, but it would be essential to severely reprimand the fraudsters in order to deter them. According to Hassink et al. (2010), it is relatively rare to find cases where fraud is detected by auditors. The big four are not the most effective in detecting fraud with an external impact, that is to say the most serious. The best non-big four audit firms are in this category. In a study carried out in Jordan, Shanikat et al. (2014) wanted to identify the existence and the effectiveness of fraud prevention mechanisms in companies listed on the ASE stock exchange.

The results revealed that the management of internal control, internal audit functions (mainly fraud review) and external audits of financial statements ranked the highest fraud prevention mechanisms in terms of percentage (100\% existence) according to the perception of auditors, financial directors and chief accounting officers. The study also showed the existence of mechanisms such as codes of conduct, independent audit committees and surprise audits. However, formal mechanisms for assessing the risk of fraud by whistleblowers specialized in this area do not seem to exist in these Jordanian companies. Financial statement fraud is costly for investors and can damage the credibility of the audit profession. To prevent and detect fraud, it is useful to know its causes. Binary choice models (eg logit and probit) are commonly used in the existing literature, however do not hold cases of undetected fraud and therefore present tests of unreliable hypotheses. Using a sample of 118 companies accused of fraud by the Securities and Exchange Commission (SEC), the authors estimated a logit model that corrects the problems associated with undetected fraud in American companies. The results indicate that only $1.43 \%$ of the cases of fraud in the financial statements were published by the S.E.C. Among the six important variables included in the traditional uncorrected logit model, three were considered insignificant in the corrected model. The probability of fraud on the financial statements is 5.12 times higher when the auditor of the company issues an unfavorable or qualified report. 


\section{Conclusion: Fraud a Complex Phenomena}

As defined and understood by the scientific and professional community, fraud is a complex phenomena. In fact, fraud can be committed by employees or non-employees. The phenomena is as old as the origin of human activities, in the beginning of the world civilization. Nowadays, the fraud phenomena is still present in all organizations, public and private, as well as in the governmental sector. Although some mechanisms exist to prevent and fight against fraud, efforts have to continue to be done. In particular, technology is used by fraudsters, like the dark web.

The governance mechanisms are still important to prevent and fight against fraud. In organizations, internal and external controls have to be reinforced. Continuing education has to be instaured for specific departments in the organizations.

Future research in the fraud area should include the new fraud techniques and the tools controlled by organizations to fight against them.

\section{References}

ACFE (2014). Report to nations on occupational fraud and abuse, 2014 global fraud survey. ACFE: Austin, USA.

Aggarwal, R., Hu, M. and Yang, J. (2015). Fraud, market reaction, and the role of institutional investors in Chinese listed firms. Journal of portfolio Management, 41(5): 92-109. Available: https://search.proquest.com/docview/1655224067?accountid=14719

Alam, P. and Petruska, K. A. (2012). Conservatism, SEC Investigation, and Fraud. Journal of Accounting and Public Policy, 31(4): 399-431.

Albrecht, C., Holland, D., Malagueno, R., S., D. and Tzafrir, S. (2015). The role of power in financial statement fraud schemes. Journal of Business Ethics, 131(4): 803-13.

Ali, J., Brockett, P. L., Golden, L. L. and Guillén, M. (2013). A robust unsupervised method for fraud rate estimation. Journal of Risk and Insurance, 80(1): 121-43.

Aris, N. A., Siti, M. A., Rohana, O. and Mustafa, M. Z. (2015). Fraudulent financial statement detection using statistical techniques: The case of small medium automotive entreprise. Journal of Applied Business Research, 31(4): 1469.

Azrina, M., Yusof, N. and Ling, L. (2014). An integrative model in predicting corporate tax fraud. Journal of Financial Crime, 21(4): 424-32.

Beneish, M. D., Lee, C. M. C. and Nichols, D. C. (2013). Earning manipulation and expected returns. Financial Analysts Journal, 69(2): 57-82.

Bierstaker, J. L., Seol, I. and Huefner, R. J. (2010). Local government fraud: the Roslyn school District case. Management Research Review, 33(3): 198-209.

Boyer, M. M. (2007). Resistance (to fraud) is futile. Journal of Risk and Insurance, 74(2): 461.

Button, M., Blackbourn, D., Lewis, C. and Shepherd, D. (2015). Uncovering the hidden cost of staff fraud: An assessment of 45 cases in the UK. Journal of Financial Crime, 22(2): 170-83. Available: https://search.proquest.com/docview/1676298713? accountid=14719

Chen, J. and Galbraith, J. (2012). Austerity and fraud under different structures of technology and resource abundance. Cambridge Journal of Economics, 36(1): 335-43.

Cohen, J., Ding, Y., Lesage, C. and Stolowy, H. (2010). Corporate fraud and managers' behavior: Evidence from the press. Journal of Business Ethics, 95(2): 271-315. Available: http://dx.doi.org/10.1007/s10551-011-0857-2

Compin, F. (2015). Tax fraud: A socially acceptable financial crime in France? Journal of Financial Crime, 22(4): 432-46. Available: http://search.proquest.com/docview/1707507057?accountid=14719

Conyon, M. J. and Lerong, H. (2016). Executive Compensation and Corporate Fraud in China. Journal of Business Ethics, 134(4): 669-91.

Cordery, C. J. and Baskerville, R. F. (2011). Charity transgressions, Trust and Accountability. Voluntas, 22(2): $197-$ 213. Available: http://dx.doi.org/10.1007/s11266-010-9132-x

Cressy, R., Cumming, D. and Mallin, C. (2012). Entrepreneurship, governance and ethics. Springer Netherlands: Dordrecht. 271-315.

Crocker, J. C., L. (2011). Addressing scientific fraud. Science, 334(6060): 1182.

Cumming, D., Leung, T. Y. and Rui, O. (2015). Gender diversity and securities fraud. Academy of Management Journal, 58(5): 1572-93.

Dalnial, H., Kamaluddin, A., Sanusi, Z. M. and Khairuddin, K. S. (2014). Accountability in financial reporting: Detecting fraudulent firms. Procedia-Social and Behavioral Sciences, 145: 61-69. Available: http://dx.doi.org/10.1006/j.sbspro.2014.06.011

Davis, J. S. and Pesch, H. L. (2013). Fraud dynamics and controls in organizations. Accounting, Organizations and Society, 38(6-7): 469-83. Available: https://doi.org/10.1016/j.aos.2012.07.005

De Cremer, D. and Wim, V. (2017). Managing unethical behavior in organizations: The need for a behavioral business ethics approach. Journal of Management and Organisation, 23(3): 437-55.

Djama, C. (2013). Fraudes à l'information comptable et financière et contrôle de l'AMF : Une étude des réactions du marché financier français. Revue française de gestion, 2(231): 133-57.

Dorminey, J., Fleming, A. S., Kranacher, M. J. and Riley, R. A. J. (2012). The evolution of fraud theory. Issues in Accounting Education, 27(2): 555-59.

Finnerty, J. D., Hegde, S. and Malone, C. B. (2016). Fraud and firm performance: Keeping the good times (apparently) rolling. Managerial Finance, 42(2): 151-72. 
Fleckinger, P., Lafay, T. and Monnier, C. (2013). Rémunération des dirigeants et risque de fraude d'entreprise. Revue économique, 64(3): 457-67.

Fligstein, N. and Rochrkasse, A. F. (2016). The causes of Fraud in the Financial Crisis of 2007 to 20019. American Sociological review, 81(4): 617-43.

Fortin-Rittberger, J. (2014). The role of infrastructural and coercive state capacity in explaining different types of electoral fraud. Democratization, 21(1): 95-117.

Fortvingler, J. and Szivos, L. (2016). Different approaches to Fraud Risk assessment and Their Implications on Audit Planning. Periodica polytechnica Social and Management Sciences, 24(2): 102-12.

Free, C. (2015). Looking through the fraud triangle: A review and call for new directions. Meditari Accountancy Research, 23(2): 175-96.

Frimpong, K. (2015). Back to basics: Fighting fraud and austerity. Journal of Financial Crime, 22(2): 219-27. Available: https://seartch.proquest.com/docview/167698715?accountid=14719

Gupta, R. and Gill, N. S. (2012). A data mining framework for prevention and detection of financial statement fraud. International Journal of Computer Applications, 50(8): 7-14.

Hammesley, J. S., Zems, K. M. and Kadous, K. (2011). How do audit seniors respond to heightened fraud risk? Auditing: A Journal of Practice and Theory, 30(3): 81-101.

Harvey, P., Martinko, M. J. and Borkowski, N. (2017). Justifying deviant behavior: The role of attributions and moral emotions. Journal of Business Ethics, 141(4): 779-95. Available: http://dx.doi.org/10.1007/s10551016-3046-5

Hasan, M. S., N., Rahman, R. A. É. and Hossain, S. Z. (2016). Corporate attributes and corporate accruals. Aestimation, (12): 24-46. Available: http://dx.doi.org/10.5605/IEB.12.2

Hass, L. H., Tarsalewka and Zhan, F. (2016). Equity incentives and corporate fraud in China. Journal of Business Ethics, 138(4): 723-42. Available: http://dx.doi.org/10.1007/s10551-015-2774-2

Hassink, H., R., M. and Bollen, L. (2010). Fraud detection, redress and reporting by auditors. Managerial Auditing Journal, 25(9): 861-81. Available: http://dx.doi.org/10.1108/02686901011080044

Hatice, U., Szewczyk, S. H. and Varma, R. (2004). Board composition and corporate fraud. Financial Analysts Journal, 60(3): 33-43.

Hoffman, V. B. and Zimbelman, M. F. (2009). Do strategic reasoning and brainstorming help auditors change their standard audit procedures in response to fraud risk? The Accounting Review, 84(3): 811-37.

Hogan, C. E., Rezaee, Z., Jr, R. A. R. and Velury, U. K. (2008). Financial statement fraud: Insights from the academic literature. Auditing. A Journal of Practice and Theory, 27(2): 231-52.

Hoi , C. K. and Robin, A. (2010). Labor market consequences of accounting fraud. Corporate Governance. The International Journal of Business in Society, 10(3): 321-33.

Holtfreter, K. (2008). Determinants of fraud losses in non-profit organizations. Non-profit Management and Learnership, 19(1): 45-63.

Hossain, M., Ashraf, K. and Feras, M. S. (2017). Caital punishment and financial reporting fraud implications for secular countries. Developing Areas, 51(2): 343-56.

Ilter, C. (2014). Misrepresentation of financial statements. Journal of financial Crime, 21(2): 215-25. Available: https://searvh.proquest.com/docview/1660746983?accountid=14719

Jacquinot, P., Pellissier-Tanon, A. and Strtak, S. (2011). La diffusion de la fraude en entreprise : le cas de la collusion tacite. Annales Des Mines-Gérer Et Comprendre, 2(104): 85-94.

Jessup, C. M. and Noblet, I. N. (2012). Fraud insights derived from stories of auditors of financial institutions. Journal of Forensic and Investigative Accounting, 4(2): 206-43.

Johansson, E. and Carey, P. (2016). Detecting fraud: The role of the anonymous reporting channel. Journal of Business Ethics, 139(2): 391-409. Available: http://dx.doi.org/10.1007/s10551-015-2673-6

Kambia-Kapardis (2016). Corporate fraud and corruption: A holistic approach to preventing financial crises. Palgrave MacMillan.

Kaplan, S. E., Pope, K. R. and Samuels, J. A. (2011). An examination of the effect of inquiry and auditor type on reporting intentions for fraud. Auditing: A Journal of Practice, 30(4): 29-49.

Khanna, V., Kim, E. H. and Lu, Y. A. O. (2015). CEO connectedness and corporate fraud. The Journal of Finance, 70(3): 1203-52.

Kramer, B. (2015). Trust, but verify: Fraud in small businesses. Journal of Small Business and enterprise Development, 22(1): 4-20.

Kummer, T. F., Singh, K. and Best, P. (2015). The effectiveness of fraud detection instruments in not-for-profit organizations. Managerial auditing Journal, 30(4/5): 435-55.

Lang, M. and Wambach, A. (2013). The fog of fraud-Mitigating fraud by strategic ambiguity. Games and Economic Behavior, 81(1): 255-75.

Le Maux, J. and Morin, D. (2011). Black and White and red all over: Lehman Brothers'inevitable bankruptcy splashed across its financial statements. International Journal of Business and Social Science, 2(20): 29-66.

Le Maux, J., Smaili, N. and Amar, W. B. (2013). De la fraude en gestion à la gestion de la fraude. From Fraud in Management to Fraud Management, 39(231): 73-85.

Leemann, L. and Bochsler, D. (2014). A systematic approach to study electoral fraud. Electoral Studies, 35(1): 3347. 
Lin, C., Huang, S. Y. and Yend, D. C. (2015). Detecting the financial statement fraud: The analysis of the differences between data mining techniques and experts' judgments. Knowledge-Based Systems, 89(1): 459-70.

Lisic, L., Silveri, S., Song, Y. and Kun, W. (2015). Accounting fraud, auditing and the role of government sanctions in China. Journal of Business Research, 68(6): 1186-95.

Lowe, D. J., Pope, K. R. and Samuels, J. A. (2015). An examination of financial sub-certification and timing of fraud discovery on employee whistleblowing reporting intentions. Journal of Business Ethics, 131(4): 757-72.

Mangala, D. and Kumari, O. (2015). Corporate fraud prevention and detection: Revisiting the literature. Journal of Commerce and Accounting Research, 4(1): 52-62.

Markelevich, A. and Rosner, R. L. (2013). Auditor fees and Fraud firms. Contemporary Accounting Research, 30(4): 1590-625.

Moyes, G. D., Young, R. and Mohamed din, H. F. (2013). Malaysian internal and external auditor perceptions of the effectiveness of red flags for detecting fraud. International Journal of Auditing Technology, 1(1): 91-106.

Moyes, G. D., Ping, L., Raymaond, M. L. and Handam, V. (2006). Internal auditors' perceptions of the effectiveness of red flags to detect fraudulent financial reporting, working paper. 1-28.

Mukoro, D., Ogijo, Y. and Faboyede, S. (2013). 2 the role of forensic accountants in fraud detection and national security in Nigeria. Manager, 17(1): 90-106.

Nia, S. H. (2015). Financial ratios between fraudulent and non-fraudulent firms: evidence from Tehran Stock Exchange. Journal of Accounting and Taxation, 7(3): 38-44.

Norazida, M. and Handley-Schachelor, M. (2014). Financial statement fraud risk mechanisms and strategies: The case studies of Malaysian commercial companies. Procedia-Social and Behavioral Sciences, 145(1): 32129.

Omar, N. B. and Din, H. F. M., 2010. "Fraud diamond risk indicator: An assessment of its importance and usage." In Paper presented at the 2010 International Conference on science and Social Research (CSSR 2010).

Oriane and Lafuente (2014). La fraude fiscal: quels coûts ? Quelles politiques? Regard croisés sur l'économie, 1(14): 143-46.

Pacolet, J. and Stren, G. S. T. (2011). Le coût des dépenses fiscales et parafiscales et de l'évasion en Belgique, HIVA. Katholieke Universiteit Leven, 1374.

Panagiotidou, E. and Intzesiliglou, N., 2016. "The morality of practices in practice procurement." In Paper presented at the pp. 306-16.

Pande, V. and Maas, W. (2013). Physician medicare fraud: Characteristic and consequences. International Journal of Pharmaceutical and Healthcare Marketing, 7(1): 8-33. Available: http://dx.doi.org/10.1108/17506121311315391

Peltier-Rivest, D. (2010). La fraude. Gestion, 35(2): 21-22.

Peltier-Rivest, D. and Lanoue, N. (2012). Thieves from within: Occupational fraud in Canada. Journal of Financial Crime, 19(1): 54-64. Available: http://dx.doi.org/10.1108/13590791211190722

Peltier-Rivest, D. and Lanoue, N. (2015). Cutting fraud losses in canadian organizations. Journal of Financial Crime, 22(3): 295-304.

Peng, L. and Roell, A. (2008). 2008. Manipulation and equity-based compensation, 98(2): 285-90. Available: http://dx.doi.org/10.1257/aer.98.2.285

Perols, J. L., Bowen, R. M., Zimmemann, C. and Samba, B. (2017). Finding needles in a haystack: Using data analytics to improve fraud prediction. The Accouting Review, 92(2): 221-45.

Perron, F. and Djelassi, S. (2015). Les comportements deviants des consommateurs vus par leurs pairs: Le cas du commerce de detail. Revue Management and Avenir, 1(75): 55-68.

Peters, S. and Maniam, B. (2016). Corporate fraud and employee theft: Impacts and costs on business. Journal of Business and Behavior Sciences, 28(2): 104-17.

Petit, S. C. and Cusin, J. (2013). Whistleblowing et resilience: Analyse d'une trajectoire individuelle. M@n@gement, 16(2): 141-75. Available: https://search.proquest.com/docview/1449565568?accountid=14719

Popoola, O. M. J., Ayoib, B. C. A. and Samsudin, R. S., 2016. "Forensic accountant and auditor knowledge and skills requirements for task performance fraud risk assessment in the nigerian public sector." In International Conference on Accounting Studies.

Power, M. (2013). The apparatus of fraud risk. Accounting, Organizations and Society, 38(6): 525-43. Available: https://doi.org/10.06/j.aos.12.07.004

Puspasari, N. and Suwardi, E. (2016). The effect of individual morality and internal control on the propensity to commit fraud: evidence from local governments. Journal of Indonesian Economy and Business, 31(2): 20819.

Ramamoorti, S. (2008). The Psychology and Social of fraud: Integrating the Behavioral Sciences component into fraud and forensic accounting curricula. Issues in Accounting Education, 23(4): 521-33.

Ravisankar, P., Ravi, V., Raghava, R. G. and Bose, I. (2011). Detection of financial statement fraud and feature selection using data mining techniques. Decision Support Systems, 50(2): 491-500. Available: https://doi.org/10.1016/j.dss.2010.11.006

Rayaan, B., Samsudin, R. S., Che-Ahmed, A. and Johnson Popoola, O. M. (2016). Capability component of fraud and fraud prevention in Saudi Arabian banking sector. International Journal of Economics and Financial Issues, 6(4S): 68-71. 
Rehman, S. S. P. and Perry, F. V. P. J. D. (2014). Corruption, constitutions, and crude in Latin America. Law and Business Review of the Americas, 20(2): 163-207.

Reinstein, A. and Taylor, E. Z. (2017). Fences as controls to reduce accountsants' rationalization. Journal of Business Ethics, 141(3): 477-88. Available: https://dx.doi.org/10.1007/s10551-015-2701-6

Robinson, H. D. and Santore, R. (2011). Managerial incentives, fraud, and monitoring. Financial Review, 46(2): 281-311.

Rossana, G. S., Adrianna, F. V., Gustavo, A. A. and Jose, D. G. D. S. (2013). Accounting fraud and whistleblowing: An empirical research on the influence of the delator's perception of accounting. Revista Universo Contabil, 9(3): 128-42. Available: https://search.proquest.com/docview/1440179467?accountid=14719

Sanusi, Z. M., Rameli, M. N. F. and Isa, Y. M. (2015). Fraud schemes in the banking institutions: Prevention measures to avoid severe financial loss. Procedia Economics and Finance, 28: 107-13. Available: http://dx.doi.org/10.1016/S2212-5671(15)01088-6

Segal, S. Y. (2016). Accounting frauds - review of advanced technologies to detect and prevent frauds 1. Economics and Business Review, 2(4): 45-64. Available: http://dx.doi.org/10.18559/ebr.2016.4.3

Shanikat, M., Al-Farah, A. and Dorgham, T. H. (2014). Occupational fraud prevention mechanisms: Jordanian companies experience. Research Journal of Finance and Accounting, 5(1): 84-92.

Shapiro, D. M. (2011). Better understanding accounting fraud. Journal of Corporate Acoounting and Finance, 22(4): 61-64.

Spire, A. (2012). Au nom de la fraude. Plein Droit, 92(1): 5.

Spire, A. and Weidenfeld, K. (2016). La tolérance des juges a la fraude fiscale: un inconscient d'institution Criminologie, 49(1): 79-98.

Tarjo and Herawati, N. (2015). Application of beneish m-score models and data mining to detect financial fraud. Procedia-Social and Behavioral Sciences, 211: 924-30. Available: http://dx.doi.org/10.106/j.sbspro.2015.11.122

Throckmorton, C. S., Mayew, W. J., Venktachalam, M. and Colls, L. M. (2015). Financial fraud detection using vocal, linguistic and financial cues. Decision Support Systems, 74(1): 78-87.

Verschoor, C. C. C. M. A. C. P. A. (2014). Fraud continues to cause significant losses. Strategic Finance, 96(2): 1112.

Wells, J. (2007). Corporate fraud handbook: Prevention and detection. 2nd edn:

Wuerges, A. F. E. and Borba, J. A. (2014). Accounting Fraud: an estimation of detection probability/Fraudes Contabeis: uma estimativa da probabilidade de deteccao/Fraudes contaables: una estimacion de la probabilidad de deteccion. Revista Brasilera de Gestao de Negocios, 16(52): 466-83.

$\mathrm{Yu}, \mathrm{F}$. and Yu, X. (2011). Corporate lobbying and fraud detection. Journal of Financial and Quantitative Analysis, 46(6): 1865-91.

Yucel, E. (2013). Effectiveness of red flags in detecting fraudulent financial reporting: An application in Turkey. Muhasebe ve Finansman Dergisi, (60).

Zager, L., Malis, S. S. and Novak, A. (2016). The role and responsibility of auditors in prevention and detection of fraudulent financial reporting. Procedia Economics and Finance, 39: 693-700. Available: http://dx.doi.org/10.1016/S2212-5671(16)30291-X

Zamzami, F., Nusa, N. D. and Timur, R. P. (2016). The effectiveness of fraud prevention and detection methods at universities in Indonesia. International Journal of Economics and Financial Issues, 6(3): 66-69.

Zawadzki, C. (2013). La maitrise du risque de fraude par des mécanismes informels. Risk of fraud management through informal internal control mechanisims. Dans Revue française de gestion, 39(231): 117-31. Available: https://www.cairn.info/revue-francaise-de-gestion-2013-2-page-117.htm\#

Zecri, J. L. (2008). La Prevention de la fraude en entreprise. Revue Française de Comptabilité, (407): 40-43.

Zhou, W. and Kapoor, G. (2011). Detecting evolutionary financial statement fraud. Decision Support Systems, 50(3): 570-75. Available: http://dxdoi.org/10.1016/j.dss.2010.08.007 